\title{
Method of retrospective evaluation of physiognomic landscape changes and its application in the West Polesie region (CE Poland)
}

\author{
Tadeusz J. Chmielewski • Agnieszka Kułak • \\ Malwina Michalik-Śnieżek
}

Received: 28 May 2013/ Accepted: 10 February 2014/Published online: 13 March 2014

(c) The Author(s) 2014. This article is published with open access at Springerlink.com

\begin{abstract}
Since the mid-twentieth century, fundamental landscape physiognomy transformations have been observed. A number of different methods of evaluation of landscape physiognomy values have been developed so far. Nonetheless, the assessment of changes occurring in landscape physiognomy still poses numerous methodological problems. The objective of the study is to propose an original "method of retrospective evaluation of landscape physiognomy changes" and to present the results of its testing in a fragment of the "West Polesie" Biosphere Reserve (CE Poland) over the period from 1838 to 2011. The method is based on the comparison of the present character of landscape physiognomy with its probable image at the beginning of the period analysed. Such a retrospective assessment of the state of landscape in the 1840s was performed based on the analysis of old topographic maps, literary and tourist descriptions, as well as the analysis of paintings, and since the 1950s also aerial and terrestrial photographs. The analysis of changes in landscape physiognomy covered a route of $12 \mathrm{~km}$. Changes in landscape physiognomy were assessed on the route along five $1-\mathrm{km}$ sections distributed fairly evenly over the entire route. Both the former and current landscape
\end{abstract}

Editor: Helmut J. Geist.

T. J. Chmielewski · A. Kułak $(\bowtie) \cdot$ M. Michalik-Śnieżek

Faculty of Landscape Ecology and Nature Conservation,

University of Life Sciences in Lublin, ul. Dobrzańskiego 37,

20-262 Lublin, Poland

e-mail: a.k.ulak@wp.pl

T. J. Chmielewski

e-mail: tadeusz.chmielewski@up.pl

M. Michalik-Śnieżek

e-mail: mmsniezek@wp.pl physiognomy values were assessed at a scale from 1 to 10 points according to five precisely defined criteria. The obtained bonitation results were presented in the form of tables and subject to comparative analysis. The results showed that in spite of the large scale of changes, certain areas retained very high physiognomic values and still represent unique genius loci of the Polesie region. These areas were suggested to be covered by particular protection. In other areas, landscape physiognomy changes have the character of discontinuation. In spite of the subjective character of individual assessments, results obtained suggest that the method is suitable for the identification of the traditional (conservative) features, and for the purposes of conservation and management of the identity of unique landscapes.

Keywords Landscape physiognomy - Landscape evaluation · Landscape changes - West Polesie

\section{Introduction}

Over the last decades, the pace of spatial development, changes in land use structure, changes in construction materials and technologies, production, and the creation of technical infrastructure have become faster than ever before. Those processes entail increasing transformations of the structure and functioning of landscape systems (Zonneveld and Forman (ed.) 1990; Antrop 2000; Jongman 2002; Lindenmeyer and Fisher 2006; Chmielewski 2012a). Those changes have also an enormous impact on landscape physiognomy. So far, a variety of methods have been developed, more or less subjective, for the assessment of the values of landscape physiognomy. Those methods can be classified into 3 main groups: (1) methods based on the 
description of the state of landscape (evaluation of characteristic features of the area), (2) methods based on the study of public preferences, and (3) methods based on quantitative holistic techniques (Buhyoff and Riesenman 1979).

Methods based on the description of the state of landscape

In the initial period of development of landscape sciences, the aesthetic values of land were one of the important elements of description (characterisation) of the analysed regions. That was the approach applied, among others, by A. Humboldt, K. Banse, or F. Younghusband (Wojciechowski 1986). It was the unique aesthetic values of landscape that contributed largely to the creation, in 1872, of the first national park in the world (West Sellars 2009).

Research methods permitting quantified evaluation and comparison of the character of physiognomy of various landscapes were not, however, developed until the first half of the twentieth century. Those methods were focused initially on the urban landscape. In the nineteen sixties, work was also begun on the development of methods for the assessment of physiognomy of the open landscape. In that group of methods, we can distinguish two approaches: (a) "ecological" and (b) aesthetic. The "ecological" approach was based primarily on point rating of the scale of diversity and of the degree of anthropogenic transformation of particular components of a landscape. That approach is based on the assumption that the quality of the view of a whole landscape can be expressed by means of summing up the values of its individual components; that a landscape can be characterised in terms of the species diversity of vegetation, the presence of animals, ecological zones, stage of succession, or other indices of ecological processes. It was also assumed that landscapes not transformed by man are, as a rule, evaluated positively as balanced and harmonious systems (Bartnicka 1989). At that time, one of the methods that found a broad application was Söhngen's method of indexation, consisting in point rating of selected elements of the natural environment, taking into account such components as land relief, surface waters and vegetation cover (Söhngen 1975).

In Poland, a great contribution to the development of methods of analysis and evaluation of the composition and values of landscape physiognomy was brought by the works of Bogdanowski and his team, relating-in terms of territory - to the scale of landscape interiors, landscape units and zones, and in terms of methodology comprising the sequence of: inventory-valorisation-design guidelines-landscape conservation and management plan (Bogdanowski et al. 1981). That team developed also a method for the estimation of changes taking place in landscape physiognomy on the basis of "series of time transects" (Bogdanowski 1998).

In the seventies of the twentieth century, Janecki pointed out that in natural landscape systems, in which there are no traces of human activity, straight lines are practically nonexistent. It was Man that introduced geometric figures into the landscape. Therefore, the degree of anthropogenic transformation of a given fragment of landscape can be determined by estimating the share of straight lines with relation to other lines observable in a view or vista (Janecki 1978).

Interesting methods of evaluation of the values of landscape through analysis of its perception were developed, among others, by Wejchert and Wojciechowski. The studies by Wejchert were focused on the urban landscape, and his method, called the method of the "curve of impressions", consisted in the presentation of the scale of tension and emotional impressions that appear in the observer when travelling through a given time-space sequence (Wejchert 1984). In turn, the studies by Wojciechowski were concerned with the aesthetics of the outof-town landscape. According to the assumptions of that author, evaluation of landscape aesthetics is a resultant of such variables as the total of the features of the observer that may have an effect on his evaluations, the sum of the circumstances of the evaluation, and the visual attractiveness of the landscape as such. That last variable includes, among other things, such aspects as the harmony of forms, diversity of forms, composition, uniqueness of features of the terrain, sense of security (Wojciechowski 1986). Both the methods of Wejchert and of Wojciechowski are based on subjective assessments and do not provide strictly replicable results. Nevertheless, the perception-based analyses of landscape are extremely important in planning work, as they permit making correct decisions concerning the preservation, correction and change of the perceived elements of the landscape (Skalski 2007).

The theory of landscape interiors and methods of analysis of landscape composition were developed, at the turn of the twentieth and twenty-first centuries, by Patoczka (2000) who focused especially on the role of landscape gates and walls and on "en suite" arrangement of interiors, connected with roads.

In turn, Rylke and Gąsowska applied, for the analysis of landscape composition, the approach known from the analysis of works of art, evaluating separately such aspects as the artistic, the aesthetic, and the "supra-aesthetic". The artistic aspect comprises, among other things, the evaluation of the composition, the dominants, subdominants, accents, and other elements of landscape units. The aesthetic values are assessed on the basis of questionnaire of evaluations of photographs of characteristic views recorded within the landscape unit under study. Whereas, the 
"supra-aesthetic" aspect consists in the evaluation of meanings of historical, religious, monumental nature, and other special emotional values of the landscape heritage of the unit under analysis (Rylke and Gąsowska 2009).

Methods based on the study of public preferences

The recently increased public interest in preserving the beauty of public land results in the development of scenic assessment based on public input. The visual quality (or value) of a landscape is rated based on an observer's individual preference of the entire landscape. Techniques based on subjective assessments of scenery combining diverse and changing perceptions of individuals are likely to be the most successful (Aoki 1999). The essence of the preference approach is judgment regarding the entire landscape, as opposed to the application of measurement techniques (Herzog 1985, Hull 1986). Questionnaires or verbal surveys are the most commonly used non-quantitative methods of sampling scenic preferences of various groups. They are a valuable source of quick information, although may involve sacrificing accuracy in favour of time efficiency. They are useful for determining preferences for extremely diverse categories of landscape. As an alternative to questionnaires, visual stimuli for evaluation can be provided, such as photographs with relevantly selected images (Hill and Daniel 2008; Barroso et al. 2012). Other stimuli, such as sound, can also be used (Bernat 2013).

Several trends can be distinguished in studies on public preferences. The most important are the psychological and phenomenological approaches.

Psychophysical methods of landscape assessment seek to determine mathematical relationships between the physical features of a landscape and the perceptual judgements of human observers. The psychological approach has been used in many studies involving dimensional analyses of people's preferences for different landscapes. These studies have demonstrated that various psychological constructs, such as complexity, mystery, legibility, and coherence, are important predictors of human landscape preferences (Buhyoff et al. 1994; Ohta 2001; Arthur and Stamps 2004). The psychological model refers to the feelings and perceptions of people who inhabit, visit, or view the landscape. A high-quality landscape evokes positive feelings, such as security, relaxation, warmth, cheerfulness, or happiness. A low-quality landscape is associated with stress, fear, insecurity, constraint, gloom, or other negative feelings.

Methods based on quantitative holistic techniques

Quantitative holistic methodologies combine two approaches: quantitative public preference surveys and landscape features inventories. Measures of landscape quality are typically systematically related to physical/biological and social features of the environment, permitting accurate predictions of the implications of environmental change $(\mathrm{Li}$ 2000; Naweh 2001).

Models represent a compromise between techniques assessing the effects of landscape elements on the overall preference by combining evaluations of individual dimensions (descriptive methods), and techniques emphasising interactions of landscape elements by evaluating the scenic quality of the entire image (preference models). This compromise creates quantitative holistic models, such as psychophysical and surrogate component models (Buhyoff and Riesenman 1979).

In their integrated landscape studies, Z. Myczkowski and T. J. Chmielewski paid attention to the issues of "landscape identity". The specificity of expression of local features of landscape creates the so-called "canon loci" which, together with the local culture and tradition, make up the "genius loci" (Myczkowski 2003). "The identity is the most profound relation between the landscape perceived by man (environment), and its historically accumulated elements: contents (culture, tradition of the place) and form (canon loci)" (Myczkowski 2009). If those features have an above-local reach, they constitute the "landscape identity" of an area, subregion, or region. The identity of various places and landscapes creates the "landscape diversity" of a region, country, and continent (Chmielewski 2012a).

Since the 1960 s, both in the descriptive inventories and in the public preference approaches, there has been a considerable increase of the role of photography in the evaluation of the aesthetic values of landscape (Crystal and Brush 1978; Law and Zube 1983; Daniel 2001). At present, photography (land-based and aerial) as well satellite images are among the basic tools used in landscape studies (Southworth et al. 2002; Chmielewski 2012a; Meire et al. 2013).

Since the 1990s, GIS techniques have been more and more extensively used in the evaluation of landscape physiognomy (Lee et al. 1999; Wu et al. 2006; Ramirez et al. 2011), along with 3D computer visualisations (Roth 2006; Griffon et al. 2011).

The growing scale of anthropogenic transformations of the environment and the simultaneous rapid development of techniques of registration of the image of the Earth, resulted in the growing importance of landscape studies involving analyses of changes occurring in the land use structure and landscape physiognomy of various regions.

In the 1990s, in the scope of studies on changes in the ecological structure of the landscape of the ŁeccznaWłodawa Lakeland, T. J. Chmielewski and his team applied among others aerial photographs and satellite images, and the method of "series of time transects". 
Chmielewski adopted relative shares of various forms of land cover (natural, semi-natural, and anthropogenic) in specific spatial units of landscapes within the study terms as an important criterion of evaluation of the degree of anthropogenic transformation of landscape. As a supplementary criterion of evaluation, the author adopted changes in the density of the network of landscape boundaries, and changes in the proportions of the natural, semi-natural, and anthropogenic "physiognomic boundaries of landscape", understood as the boundaries of spatial reach of various forms of land cover (Chmielewski 2006; Chmielewski and Chmielewski 2010).

In North Ethiopia Meire, the team applied an interesting method involving GIS techniques to develop retrospective maps of changes in the land use structure and cover based on old terrestrial photographs (Meire et al. 2013). In the scope of the reconstruction of environmental changes in and around the Okavango Delta region, Hamandawana \& Chanda used in turn, archival maps, literary descriptions, drawings, and photographs, confronted with the current maps of land use structure (Hamandawana and Chanda 2013). The authors, however, were not concerned with the evaluation of changes in landscape physiognomy, i.e. its emotional interaction, composition values, aesthetic values, etc.

GIS techniques permit a study of the structure and processes of anthropogenic transformations of landscapes much more accurate than that conducted a little over a decade ago. The popularity and compatibility of digital cameras permit easy monitoring of changes taking place also in landscape physiognomy.

Nonetheless, no precise quantitative methods have been developed for the evaluation of landscape physiognomy changes over periods longer than several decades which would relate to past centuries, when there were no techniques of photochemical or digital recording of images.

Pursuant to the recommendations of the European Commission regarding the implementation of the European Landscape Convention (2000), studies on landscape physiognomy concerning historically remote periods with no reliable scientific elaborations and photographic documentation available should make use of works of artpaintings and drawings, literary descriptions, and other iconographic sources. Comparative studies covering relatively recent periods of the history of a given area with abundant documentation should use and compare the same methods of representation and landscape physiognomy analysis as much as possible (LSDCELC 2006).

The same approach was applied by Kułak and Chmielewski (2010) in their attempt to evaluate the scale of changes in the features typical of the landscape physiognomy of West Polesie recorded in the nineteenth century art, literature, and songs.
The assessment of changes in landscape physiognomy still poses numerous methodological problems. They primarily result from the criteria of evaluation of the aesthetic value of areas and objects changing with the development of civilisation (Eco 2004), but also from the common scarcity of data on the appearance of particular regions and places in previous decades (particularly in periods before the common use of photographic documentation). This calls for the development of new methods and determination of the scope of recording changes in the physiognomy of landscape with features deserving protection as unique heritage of nature and culture. Such methods should also be applicable in the reconstruction of valuable landscapes that should be recreated or constitute an important system of reference for contemporary shaping of regional identity.

\section{Proposal of a new method of assessment of landscape physiognomy changes}

The inspiration for the development of a method of evaluation of changes taking place in landscape physiognomy was the method of the "curve of impressions" of Wejchert (1984), modified by Chmielewski (2012a) for the purposes of integrated assessment of aesthetic values and degree of anthropogenic transformation of landscape, as well as the recommendations contained in the EC Report concerning the implementation of the European Landscape Convention (2000).

The method developed, named the "method of retrospective evaluation of landscape physiognomy changes", consists of five stages.

Stage one includes: (a) selection of the area to be studied, (b) collection of materials and source documents on the area studied, (c) determination of dates (periods) for which the assessments of landscape physiognomy changes will be elaborated, (d) plotting on a map of the study area the route of March, and on the route several 1-kilometre sections on which the current landscape values of the study area will be evaluated. The map scale should be adapted to the size of the study area and to the length of the chose marching route. Preferred scales: from 1: 50,000 to 1: 5,000.

Stage two includes the field work. Following the route selected in Stage 1, on foot or on a bicycle, the current landscape values within the fields of view on both sides of the tested 1-km section are evaluated taking into account five criteria:

1. The extent o viewing vistas (richness of landscape resources).

2. The naturalness and distinctness of nature components (values of nature landscape).

3. The regional identity and distinctness of physiognomy of cultural components (values of cultural landscape). 
Table 1 Model table for landscape physiognomy values evaluation on selected sections of the route studied

\begin{tabular}{|c|c|c|c|c|c|c|c|}
\hline Item & Criteria of evaluation & Section 1 & Section 2 & Section 3 & $\ldots$ & Section $n$ & Total \\
\hline 1 & Extent o viewing vistas (richness of landscape resources) & & & & & & \\
\hline 2 & $\begin{array}{l}\text { Naturalness and distinctness of nature components } \\
\text { (values of landscape, nature) }\end{array}$ & & & & & & \\
\hline 3 & $\begin{array}{l}\text { Regional identity and distinctness of cultural components } \\
\text { (values of cultural landscape) }\end{array}$ & & & & & & \\
\hline 4 & Harmony of nature and culture & & & & & & \\
\hline 5 & $\begin{array}{l}\text { Emotional content of landscape (picturesqueness, photogenic } \\
\text { values, creative inspiration) }\end{array}$ & & & & & & \\
\hline & Total & & & & & & \\
\hline
\end{tabular}

4. The harmony of nature and culture.

5. The emotional content of the landscape (picturesqueness, photogenic values, creative inspiration).

The value of the area, based on the above criteria, is evaluated in the scale of 1-10 points, and the points are summed both in relation to the values of a specific section of the route and in relation to the particular criteria evaluated on the whole route studied. The results are entered in a Table 1.

It is recommended to conduct the evaluation 4 times a year (in the spring, summer, autumn and winter periods), and the results obtained should be used to calculate the mean rating.

Stage three consists in conducting several interviews with old inhabitants of localities situated along the route studied, or in its immediate vicinity, on the appearance of the area studied in the preceding or several preceding time transects. The number of such interviews should be adapted to the length and diversity of the route and to the density of population of the study area. This stage may not be necessary if the author of the study being conducted remembers well the study area from the preceding time transect (his is the case in this study).

Stage four comprises the chamber works. Based on analysis of archival maps, aerial photographs, ground photographs, scientific and technical documentation, results of interviews, as well as on the basis of analysis of literary works and paintings - an attempt is made at the retrospective evaluation of the same sections of the route, according to the same set of criteria, for several historical time transects (e.g. from before 50 and 25 years). Results of the evaluations for the particular ears are entered in Tables analogous to those used in Stage 1 (Table 1).

Stage five includes the finishing work. Comparing the results obtained, estimation is made of the character and scale of changes that have taken place in the landscape physiognomy of the study area, and conclusions are formulated on the directions of conservation, revalorisation, restoration or revitalisation of the area under analysis.
Area of method testing and time transects analysed

The area selected for testing the method was a fragment of the central part of the "West Polesie" Biosphere Reserve. That Biosphere Reserve was created in 2002, on an area of $1,39,917$ ha, to protect an exceptionally valuable, in terms of nature value, complex of lakes, peatbogs and forests, and a landscape of arable lands under extensive use and traditional villages of West Polesie (Chmielewski ed. 2005). Within the boundaries of that Biosphere Reserve, there are various categories of protected areas, including the Polesie National Park, 3 landscape parks, 14 Natura 2000 sites, 10 nature reserves (Fig. 1).

The area selected for testing the method is situated in the north-west part of the Polesie National Park and in its buffer zone, between the villages of Orzechów Nowy to the west, Komarówka and Zienki to the north, Wola Wereszczyńska to the east, and Jagodno and Zawadówka to the south. The boundaries of the study area defined in this way included the lakes Zagłębocze, Gumienko, Moszne and Karaśne, the peatbog complex "Lejno", and fragments of two watercourses: Piwonia and Bobryk.

Within that area-like in most of the territories of the Łęczna-Włodawa Lakeland, from the beginning of the twentieth century, significant changes have taken place in the water relations, in the land use structure and in the character of landscape physiognomy (Chmielewski 2006; Kułak and Chmielewski 2010). The choice of that particular area for the study resulted from, among other things, the most spectacular change - the elimination (drainage), in the first half of the twentieth century, of Lake Lejno-previously one of the largest (ca. $133 \mathrm{ha}$ ) natural reservoirs in the region.

The time transects adopted for the study of the landscape physiognomy changes were the years: (a) 1838 (the year of creation of a "quartermaster's map"); (b) 1986-1990 (work on the documentation for the creation of the Polesie National Park); (c) year 2011 (Figs. 2, 3, 4).

Within the test area, a walking route was plotted, with length of ca. $12 \mathrm{~km}$, that led from the village of Orzechów 
Fig. 1 Map of protected areas included in the "West Polesie" Biosphere Reserve. 1 "West Polesie" Biosphere Reserve, 2 area for which the historicallandscape study was performed, 3 national park, 4 national park buffer zone, 5 landscape park, 6 projected landscape park, 7 nature reserve, 8 projected nature reserve

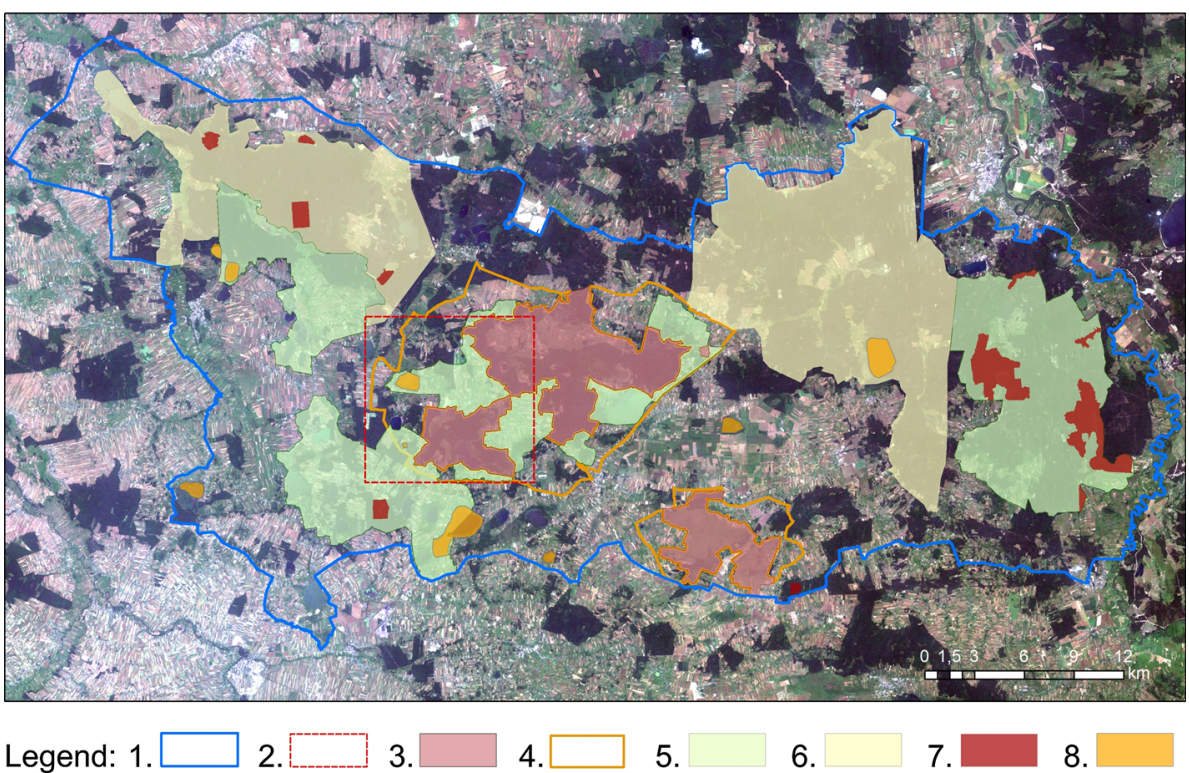

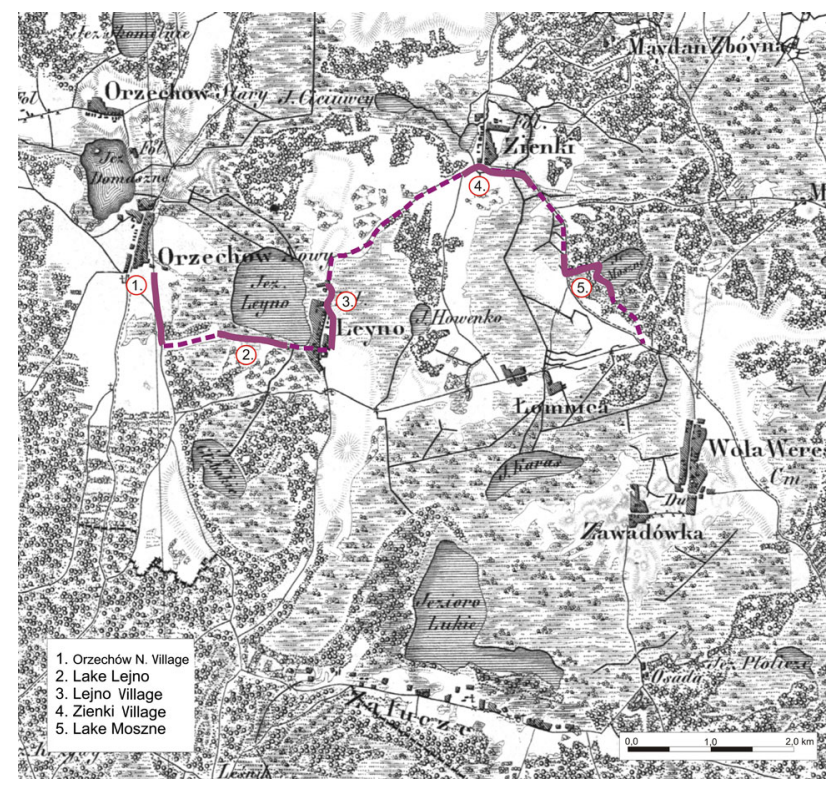

Fig. 2 Quartermaster's map published in 1838. Study area and the route of March

Nowy, along the edge of the basin of the former lake Lejno to the village of Lejno, then through the valley of the watercourse Bobryk to the villages Zienki and Jamniki, to and along the didactic path on lake Moszne. Along that route five $1-\mathrm{km}$ sections were designated, on which the aesthetic values of the landscape were evaluated (Figs. 2, 3, 4).

\section{Results}

The evaluation of the current landscape values of the study area was conducted in 2011, on five 1-km sections situated

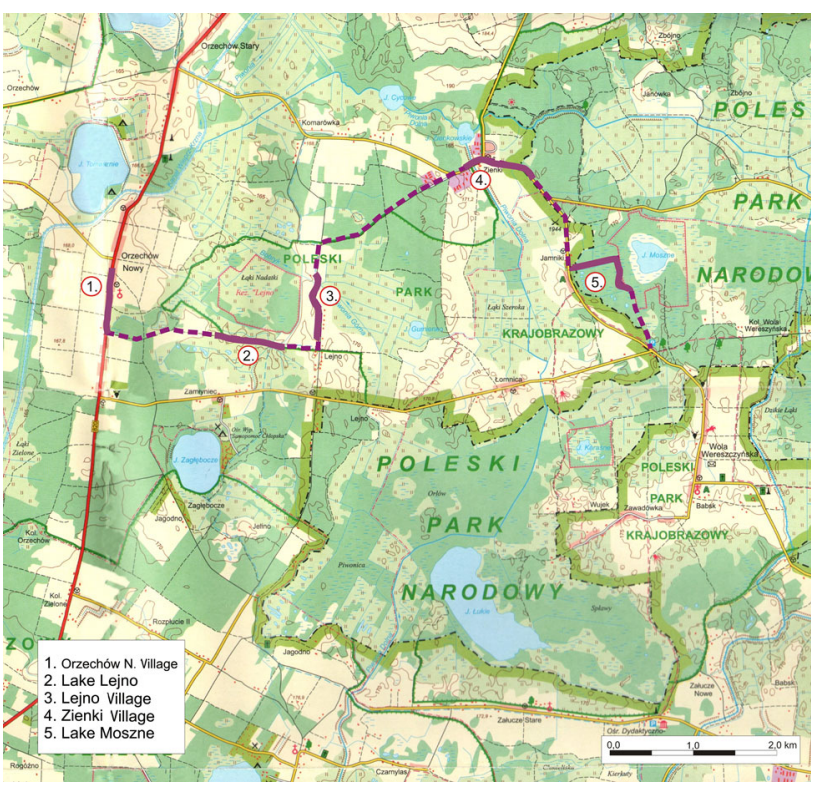

Fig. 3 Topographic map published in 1990. Study area and the route of March

along the chosen route. The sections covered: (1) village Orzechów Nowy; (2) basin of the former lake Lejno; (3) village Lejno; (4) village Zienki with buildings remaining from the former ate Farm (PGR); (5) lake Moszne with adjacent peatbog and forest (Figs. 2, 3, 4). The results of the evaluations are presented in Tables 2, 3, 4 and in Fig. 5.

The study shows that—in general — the landscape values of the study area have undergone considerable deterioration (Fig. 5). This is the most observable in the case of village Zienki, with abandoned and run-down post-socialist 
buildings of a large State Farm (PGR). The smallest scale of degradation of the aesthetic values of the landscape was observed for the surroundings of the basin of the former lake Lejno. Following the disappearance of the lake itself, within its basin there appeared fairly attractive in terms of

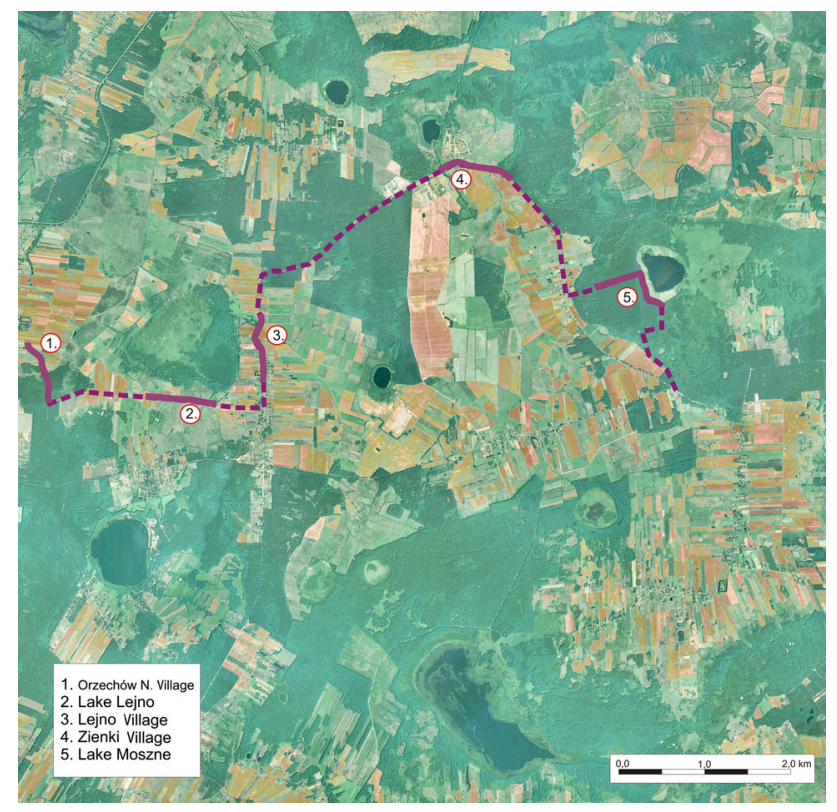

Fig. 4 Orthophotmap (2007). Study area and the route of March landscape value peatbogs, waterlogged grasslands, and alder carr. As before, it is surrounded by picturesque fallows and dry pasture lands, intersected by a gently undulating sandy road (Fig. 6).

In this case, the drastic changes in the ecosystems of the lake basin did not produce the effect of significant degradation of the aesthetic values of the surrounding landscape, as the system of ecosystems related with the lake has been successively replaced by other, but also visually attractive ecosystems: peatbog, meadow, and forest. Whereas, the terrain surrounding the lake basin retained its previous character and regional identity.

Highly surprising is the notable deterioration of the landscape values of the surroundings of lake Moszne, situated in the Polesie National Park. Large-scale drainage of expansive peatbogs, conducted in the area in the $60 \mathrm{~s}$ and $70 \mathrm{~s}$ of the twentieth century (i.e. before the national park was created), as well as the deficit of hydrological supply continuing over successive decades, resulted first in the disappearance of - so characteristic for the Polesie landscape-mid-peatbog stagnant waters and small water bodies, and then fast overgrowing of both the lake itself (with reed communities), and the peatbog (with reed rushes and swamp-forest communities). The landscape of expansive water-peatbog plains has been replaced by a forest landscape, with patches of reed vegetation (Figs. 7, $8,9,10)$.
Table 2 Retrospective evaluation of landscape physiognomy values from Orzechów Nowy village to lake Moszne in 1838

Table 3 Retrospective evaluation of landscape physiognomy values from Orzechów Nowy village to lake Moszne in the years 1986-1990

\begin{tabular}{|c|c|c|c|c|c|c|c|}
\hline Item & Criteria of evaluation & $\begin{array}{c}\text { Orzechów } \\
\text { Nowy }\end{array}$ & $\begin{array}{c}\text { Lake } \\
\text { Lejno }\end{array}$ & $\begin{array}{c}\text { Village } \\
\text { Lejno }\end{array}$ & $\begin{array}{c}\text { Village } \\
\text { Zienki }\end{array}$ & $\begin{array}{c}\text { Lake } \\
\text { Moszne }\end{array}$ & TOTAL \\
\hline 1 & $\begin{array}{c}\text { Extent o viewing vistas } \\
\text { (richness of landscape resources) }\end{array}$ & 3 & $\mathbf{1 0}$ & 4 & 4 & $\mathbf{1 0}$ & 31 \\
\hline 2 & $\begin{array}{c}\text { Naturalness and distinctness of nature } \\
\text { components (values of landscape, nature) }\end{array}$ & 3 & $\mathbf{1 0}$ & 4 & 4 & $\mathbf{1 0}$ & 31 \\
\hline 3 & $\begin{array}{c}\text { Regional identity and distinctness of cultural } \\
\text { components (values of cultural landscape) }\end{array}$ & 8 & $\mathbf{1 0}$ & $\mathbf{1 0}$ & 7 & $\mathbf{1 0}$ & 45 \\
\hline 4 & Harmony of nature and culture & $\mathbf{1 0}$ & $\mathbf{1 0}$ & $\mathbf{1 0}$ & $\mathbf{1 0}$ & $\mathbf{1 0}$ & $\mathbf{5 0}$ \\
\hline 5 & $\begin{array}{c}\text { Emotional content of landscape } \\
\text { (picturesqueness, photogenic values, } \\
\text { creative inspiration) }\end{array}$ & 9 & $\mathbf{1 0}$ & $\mathbf{1 0}$ & 9 & $\mathbf{1 0}$ & 48 \\
\hline & TOTAL & 33 & $\mathbf{5 0}$ & 38 & 34 & $\mathbf{5 0}$ & $\mathbf{2 0 5}$ \\
\hline
\end{tabular}

\begin{tabular}{|c|c|c|c|c|c|c|c|}
\hline Item & Criteria of evaluation & $\begin{array}{c}\text { Orzechów } \\
\text { Nowy }\end{array}$ & $\begin{array}{c}\text { Lake } \\
\text { Lejno }\end{array}$ & $\begin{array}{c}\text { Village } \\
\text { Lejno }\end{array}$ & $\begin{array}{c}\text { Village } \\
\text { Zienki }\end{array}$ & $\begin{array}{c}\text { Lake } \\
\text { Moszne }\end{array}$ & TOTAL \\
\hline 1 & $\begin{array}{c}\text { Extent o viewing vistas } \\
\text { (richness of landscape resources) }\end{array}$ & 2 & $\mathbf{9}$ & 4 & 2 & 6 & 23 \\
\hline 2 & $\begin{array}{c}\text { Naturalness and distinctness of nature } \\
\text { components (values of landscape, nature) }\end{array}$ & 2 & 7 & 3 & 1 & 8 & 21 \\
\hline 3 & $\begin{array}{c}\text { Regional identity and distinctness of cultural } \\
\text { components (values of cultural landscape) }\end{array}$ & 6 & 5 & 8 & 1 & 2 & 22 \\
\hline 4 & Harmony of nature and culture & 4 & 6 & 7 & 1 & 7 & 25 \\
\hline 5 & $\begin{array}{c}\text { Emotional content of landscape } \\
\text { (picturesqueness, photogenic values, creative } \\
\text { inspiration) }\end{array}$ & 5 & 7 & $\mathbf{9}$ & 1 & 8 & $\mathbf{3 0}$ \\
\hline & TOTAL & 19 & $\mathbf{3 4}$ & 31 & 6 & 31 & $\mathbf{1 2 1}$ \\
\hline
\end{tabular}


Table 4 Evaluation of landscape physiognomy values from Orzechów Nowy village to lake Moszne in 2011

\begin{tabular}{|c|c|c|c|c|c|c|c|}
\hline Item & Criteria of evaluation & $\begin{array}{c}\text { Orzechów } \\
\text { Nowy }\end{array}$ & $\begin{array}{c}\text { Lake } \\
\text { Lejno }\end{array}$ & $\begin{array}{c}\text { Village } \\
\text { Lejno }\end{array}$ & $\begin{array}{c}\text { Village } \\
\text { Zienki }\end{array}$ & $\begin{array}{c}\text { Lake } \\
\text { Moszne }\end{array}$ & TOTAL \\
\hline 1 & $\begin{array}{c}\text { Extent o viewing vistas } \\
\text { (richness of landscape resources) }\end{array}$ & 1 & $\mathbf{9}$ & 3 & 2 & 5 & 20 \\
\hline 2 & $\begin{array}{c}\text { Naturalness and distinctness of nature } \\
\text { components (values of landscape, nature) }\end{array}$ & 2 & 6 & 2 & 1 & 7 & 18 \\
\hline 3 & $\begin{array}{c}\text { Regional identity and distinctness of cultural } \\
\text { components (values of cultural landscape) }\end{array}$ & 5 & 6 & 6 & 1 & 2 & 20 \\
\hline 4 & $\begin{array}{c}\text { Harmony of nature and culture } \\
5\end{array}$ & $\begin{array}{c}\text { Emotional content of landscape } \\
\text { (picturesqueness, photogenic values, creative } \\
\text { inspiration) }\end{array}$ & 4 & 8 & 5 & 1 & 5 \\
\hline & \begin{tabular}{c} 
TOTAL \\
\hline
\end{tabular} & 15 & $\mathbf{3 7}$ & 22 & 6 & 26 & $\mathbf{2}$ \\
\hline
\end{tabular}

Whereas, the village Lejno retained all its values of cultural heritage until the mid- $80 \mathrm{~s}$ of the twentieth century (Figs. 11, 12). At present, dominant in the village are summer houses, preserving certain elements of the regional style (Fig. 13).

\section{Discussion}

The large-scale dynamic changes currently taking place in land use structure, land use technology, and in landscape physiognomy provide a stimulus for undertaking work on the systematic recording and evaluation of the successive phases of those transformations. At the same time, however, there is an increasing need of relating the results of contemporary studies to the past- to the natural and cultural models of identity of the particular regions (Chmielewski 2012b; Myczkowski 2012). Frequently, however, the archival data on the characteristic features of the area studied (and especially on its physiognomy) are very general, imprecise, and fragmentary. Moreover, they have been often acquired with methods that today can hardly be considered as scientific. Hence, the need of developing a modern method permitting the retrospective evaluation of characteristic features of the landscape of the area studied, in several time transects, on the basis of a set of specific source materials. This paper presents a proposal of such a method, and the results of its preliminary testing on a fragment of the area of the "West Polesie" Biosphere Reserve.

Almost from the beginning of undertaking attempts at quantitative evaluation of landscape quality, there has been an ongoing discussion among the researchers as to whether landscapes possess an inherent, objective beauty that could be, somehow, measurable or comparable, or whether scenic beauty is a value that can only be subjectively ascribed to a given area or a specific landscape (Shuttleworth 1980). Wojciechowski (1986), and then Orland et al. (1995) as well as numerous other

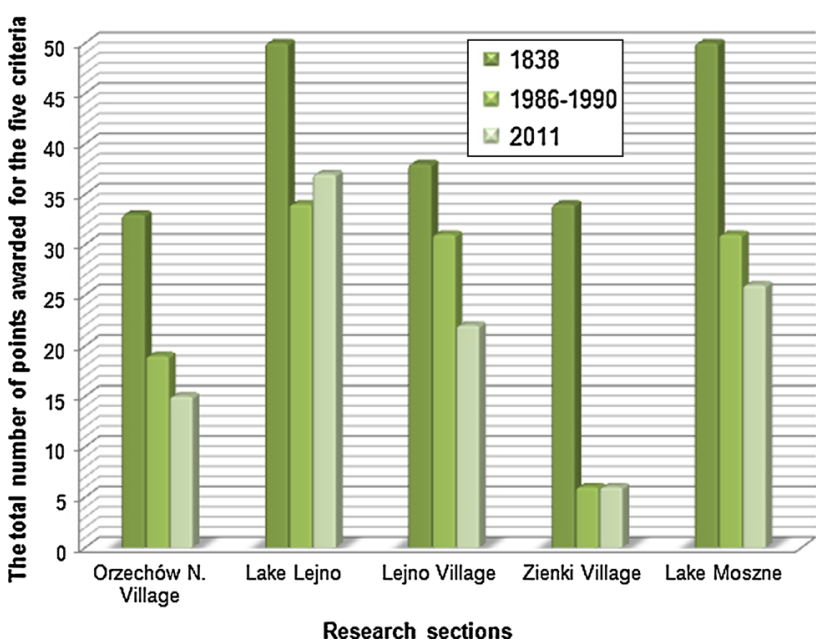

Fig. 5 Summary assessment of scenic values of the test sections in the particular years

researchers described qualitative methods of evaluation of landscape physiognomy, focused on the evaluation of landscape composition on the basis of opinions of interviewed persons, as well as quantitative methods consisting in measurement of selected physical parameters within the immediate field of view. Most of those methods are based on the assumption that there exists a broad social consensus concerning the evaluation as to which areas are considered to be landscapes with high aesthetic values and which as ones little attractive. This assumption is related with another, namely that "visual quality" is a property inseperably connected with landscape, which can be objectively ascertained (Jacques 1980). However, specific evaluations of landscape quality, made by various people, will always be more or less biased due to their individual, personal preferences.

The subjectivism of assessments is even greater in the case of attempts at analysis of changes in landscape in successive time transects. The credibility of such assessments is fundamentally dependent on the following: 


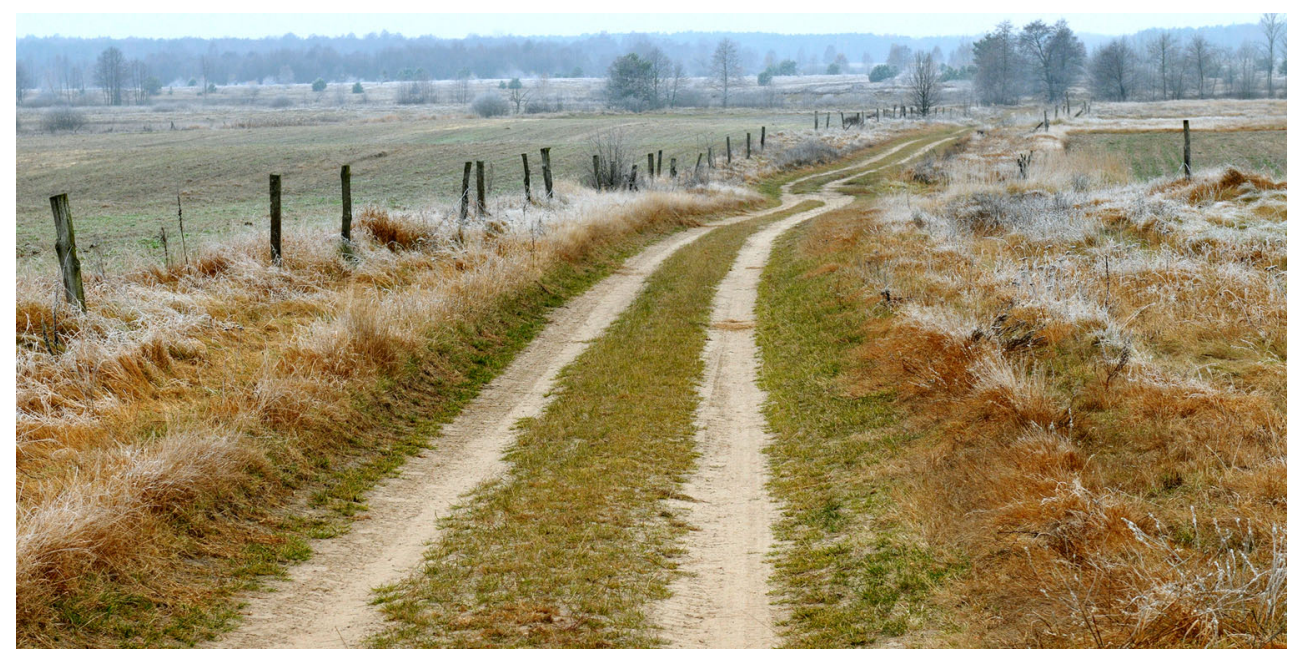

Fig. 6 Way to the basin of the former lake Lejno. Photo: T. J. Chmielewski 2011

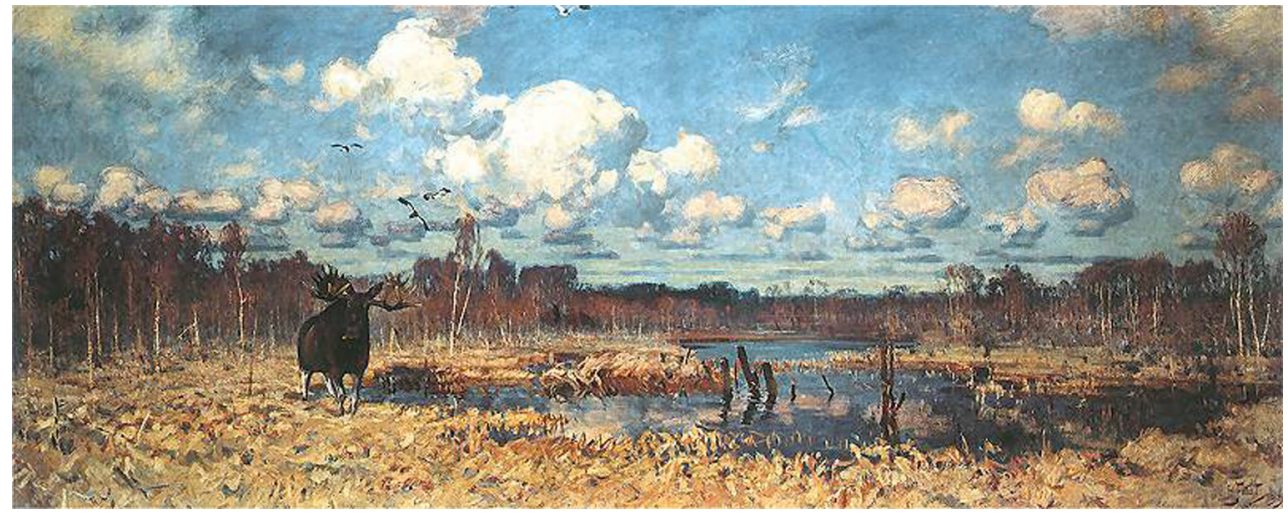

Fig. 7 Polesie landscape from the late nineteenth/early twentieth century, captured in the painting by Julian Fałat: Moose at the Polesie 1899

Fig. 8 Land use structure of the catchment basin of lake Moszne in 1952 (photoinerpretative map). Legend: 1 catchment boundary, 2 water table of the lake, 3 stagnant waters, 4 peat pits, 5 nympheids, 6 reed communities, 7 moor, moss, and sedge communities, 8 turfy lowmoor, 9 peatbog-dwarf shrub communities, 10 scrub communities, 11 forests, 12 meadows, 13 fields, 14 buildings, 15 plots with housing (Chmielewski and Chmielewski 2010)

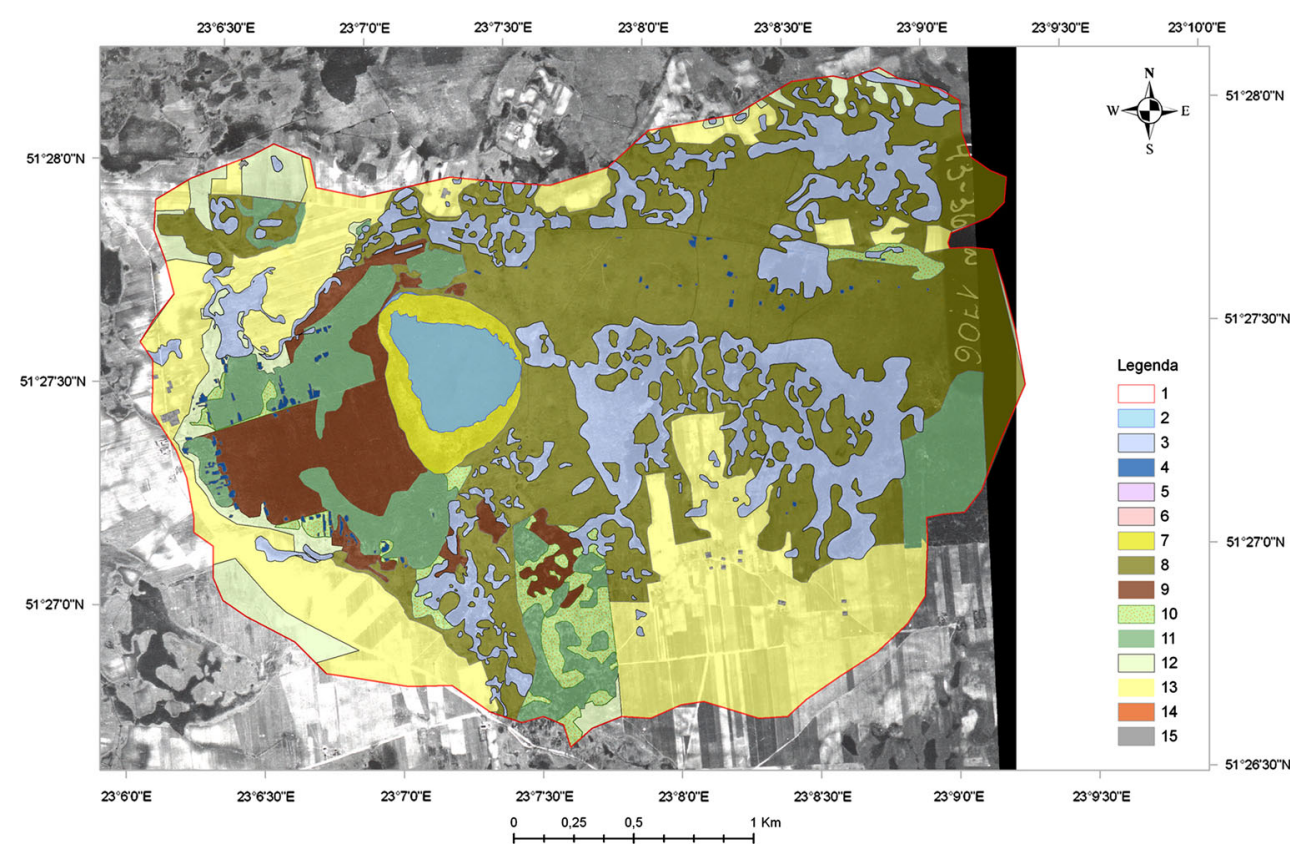




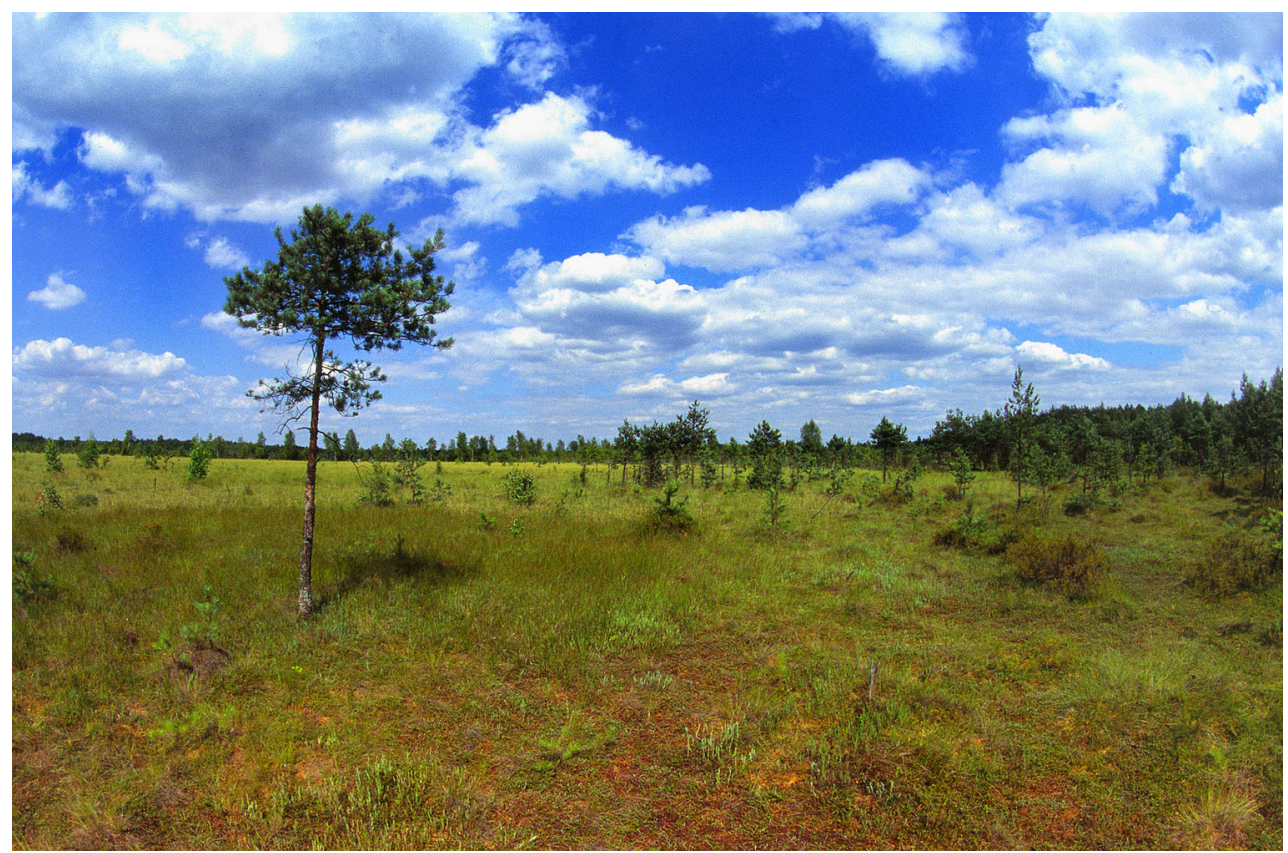

Fig. 9 Transitional moor surrounding Lake Moszne. Photo: T. J. Chmielewski 1989

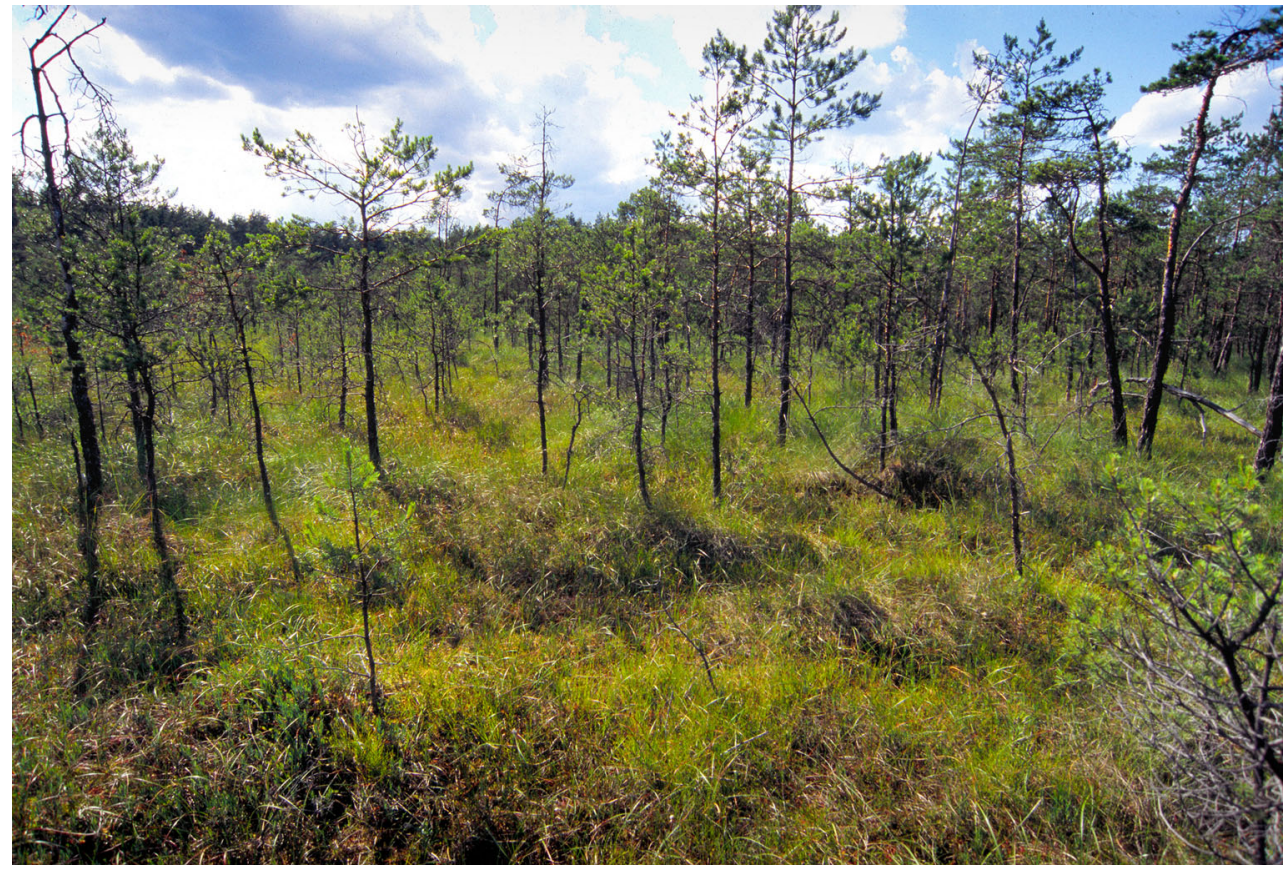

Fig. 10 Overgrown peatbog by Lake Moszne. Photo: T. J. Chmielewski 2011

- The amount and quality of accumulated source materials (maps, aerial photographs, land photographs, descriptions, etc.);

- The knowledge and experience of the author (authors) of the assessments, and especially personal long-term knowledge of the area studied.
The consideration and analysis of what and how has changed in the landscape is of great importance for the frame of mind of a person, for building his/hers bond with the region, sense of security, or the opposite- the sense of threat and frustration. Analysis of the character of changes taking place in the landscape is also of great importance for the creation of 

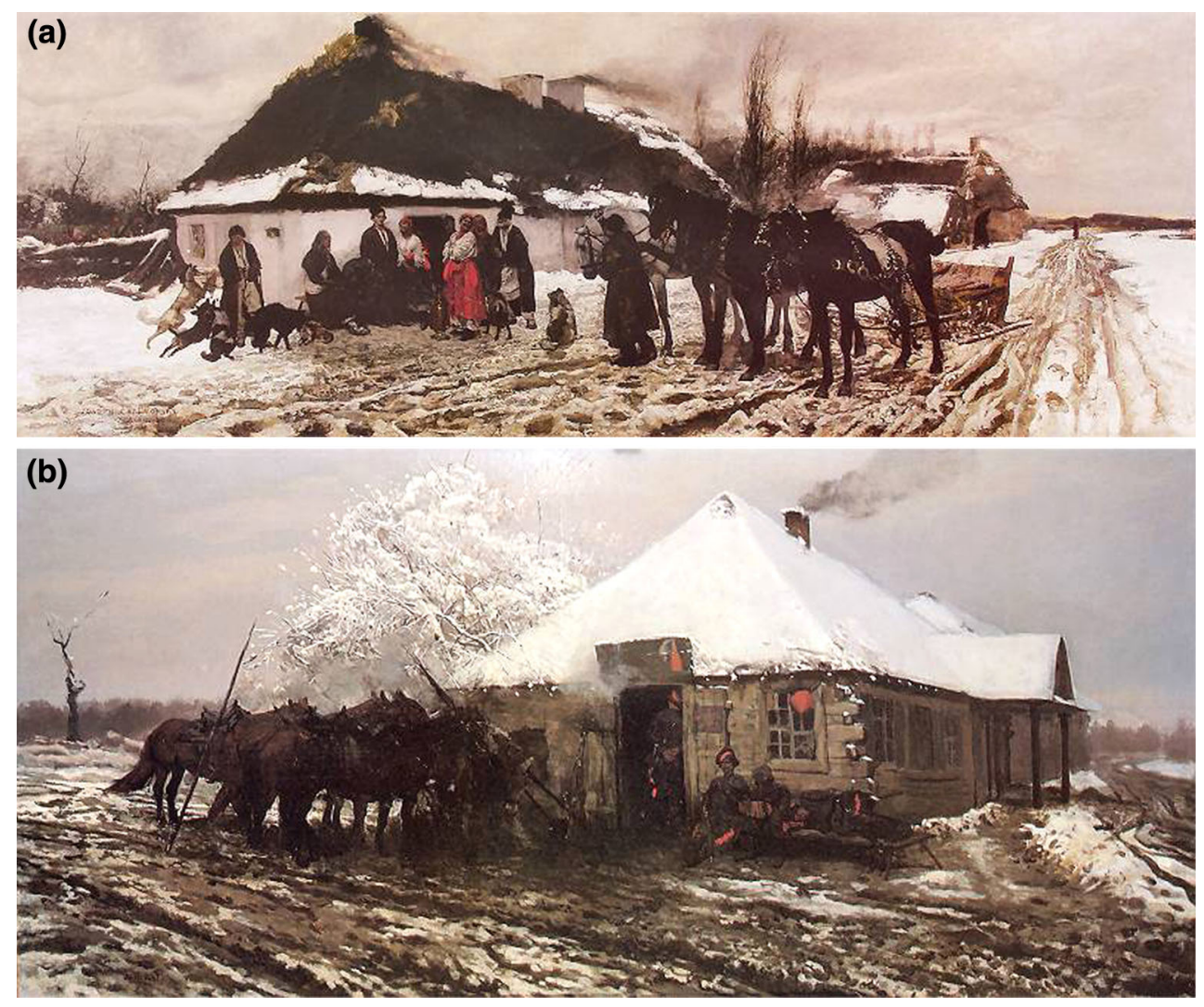

Fig. 11 Traditional village huts on the Polesie region, captured by Joseph Chełmoński. a In Front of the Inn 1876, b Cossacks in Front of the Inn 1881

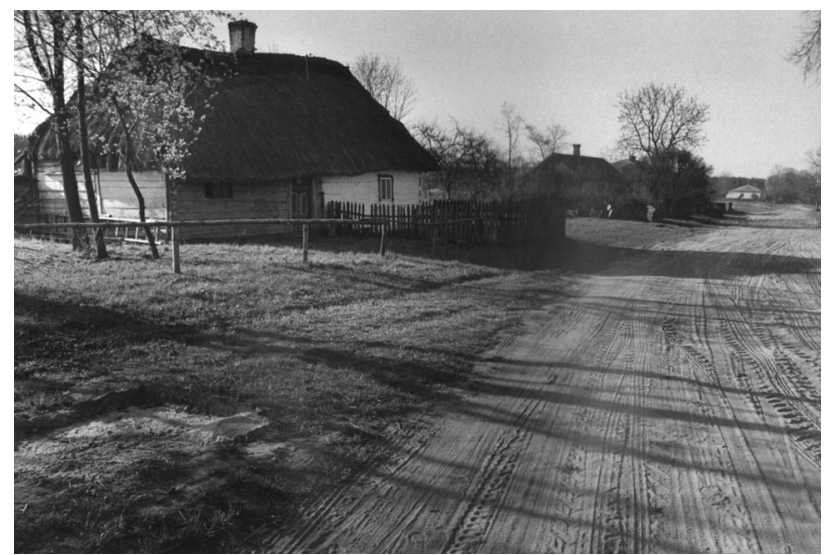

Fig. 12 Lejno village in the second half of the $80 \mathrm{~s}$, 20th ct. Photo: T. J. Chmielewski 1986

visions of future development of this earth: augmenting of positive trends, elimination of mistakes, protection of areas and objects of special value for the natural and cultural heritage.

\section{Conclusions}

1. The presented study on changes in the physiognomy of a fragment of the area of the "West Polesie" Biosphere

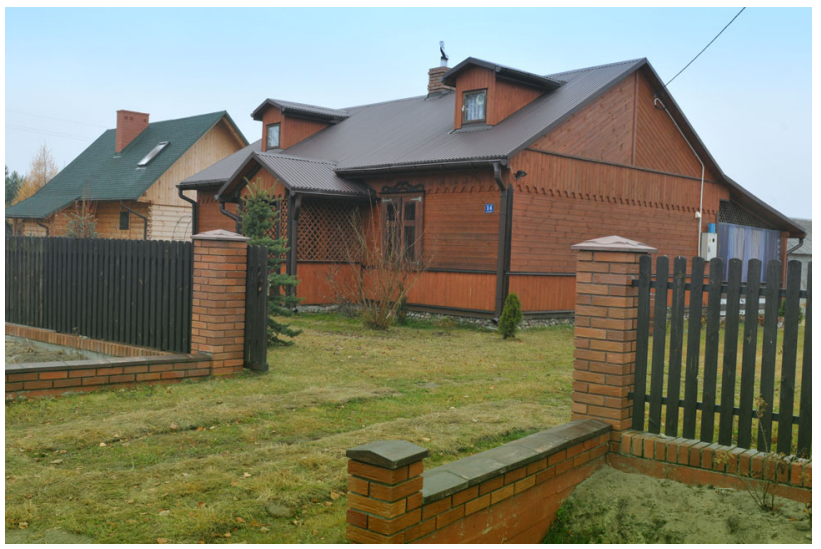

Fig. 13 Lejno village summer houses in the beginning of the twentyfirst century. Photo: T. J. Chmielewski 2011

Reserve is the first attempt at practical application of the method of retrospective evaluation of landscape physiognomy changes. In spite of the subjectivism of the individual assessments, the results obtained indicate suitability of the method for the purposes of identification of traditional (conservative) features, and for the conservation and management of the identity of unique landscapes. 
2. The results of the study conducted on the selected fragment of the Biosphere Reserve indicate, among other things, the need of special protection of the landscape values of the region of the former lake Lejno, including the consideration of a possibility of partial restoration of water table in the natural depression. There is also a need of more determined, active conservation undertakings aimed at wetland restoration in the region of lake Moszne. Likewise, it is also necessary to elaborate a catalogue of regional village and summer-house architecture, and successive implementation of designs and solutions contained therein in the villages of Orzechów Nowy and Lejno. The village Zienki requires a fundamental re-composition and revitalisation.

3. The presented method is relatively easy to apply in various landscapes under the condition of obtaining rich and reliable historical source materials.

Open Access This article is distributed under the terms of the Creative Commons Attribution License which permits any use, distribution, and reproduction in any medium, provided the original author(s) and the source are credited.

\section{References}

Antrop M (2000) Changing patterns in the urbanized countryside of Western Europe. Landsc Ecol 15:257-270

Aoki Y (1999) Review article: trends in the study of the psychological evaluation of landscape. Landsc Res 24(1):85-94

Arthur E, Stamps L (2004) Mystery, complexity, legibility and coherence: a meta-analysis. J Environ Psychol 24(1):1-16

Barroso FL, Pinto-Correia T, Ramos IL, Surova D, Menezes H (2012) Dealing with landscape fuzziness in user preference studies: photo-based questionnaires in the Mediterranean context. Landsc Urban Plann. 104(3-4), 15:329-342

Bartnicka M (1989) Perception of the environment in geographical studies (in Polish). Przegl Zagran Lit Geogr 2:5-27

Bernat S (2013) Sound and sacrum in landscape. Prace Komsji Krajobrazu Kulturowego Nr 21:11-22

Bogdanowski J (1998) Conservation and protection of cultural landscape (Evolution and methods) (in Polish). Teki Krakowskie. Vol. VI. Regionalny Ośrodek Studiów i Ochrony Środowiska Kulturowego w Krakowie. Kraków, pp. 1-224

Bogdanowski J, Łuczyńska-Bruzda M, Novák Z (1981) Landscape architecture (in Polish). PWN Warszawa-Kraków:1-246

Buhyoff GJ, Riesenmann MF (1979) Experimental manipulation of dimensionality in landscape preference judgements: a quantitative validation. Leisure Sci 2:221-238

Buhyoff GJ, Miller PA, Roach JW, Zhou D, Fuller LG (1994) An AI methodology for landscape visual assessments. AI Appl 8:1-13

Chmielewski TJ (ed) (2005) "West Polesie" Biosphere Reserve: values, functioning, perspectives of development. Monograph of a region (in Polish). Poleski Park Narodowy; Wojewoda Lubelski. Lublin, Urszulin pp 1-206

Chmielewski TJ (2006) Changes in landscapes of the ŁęcznaWłodawa Lakeland and transformations of their biological diversity after 1950 (in Polish) In: Guty-Korycka M, Kędziora A, Starkel L, Ryszkowski L (eds) Długoterminowe przemiany krajobrazu Polski w wyniku zmian klimatu i użytkowania ziemi.
Komitet Narodowy ds. Międzynarodowego Programu „Zmiany Geosfery i Biosfery” PAN; Zakład Badań Środowiska Rolniczego i Leśnego PAN, Poznań, pp 237-252

Chmielewski TJ (2012a) Landscape systems: Structure, functioning, planning (in Polish). Wydawnictwo Naukowe PWN Warszawa, pp $1-452$

Chmielewski TJ (2012b) Landscape style diagnosis and design (in Polish). Problemy Ekologii Krajobrazu XXXIII:31-52

Chmielewski TJ, Chmielewski S (2010) Processes of disappearance of lake and peatbog ecosystems in the region of the Polesie National Park since the middle of the 20th century and perspectives of their conservation (in Polish). Problemy Ekologii Krajobrazu, T. XXVI: 121-134

Crystal JH, Brush RO (1978) Measuring scenic quality at the urban fringe. Landsc Res 3(3):9-14

Daniel T C (2001) Whither scenic beauty? Visual landscape quality assessment in the 21st century. Landsc Urban Plan 54(1-4), 25: 267-281

Eco U (2004) Storia della bellezza. RCS Libri S.p.A. Bompiani, Milano, pp 1-438

European Landscape Convention (2000) Florence, 20 October 2000. (www.coe.int/europeanlandscapeconvention)

Griffon S, Nespoulous A, Cheylan JP, Marty P, Auclair D (2011) Virtual reality for cultural landscape visualization. Virtual Real 15(4):279-294

Hamandawana H, Chanda R (2013) Environmental change in and around the Okavango Delta during the nineteenth and twentieth centuries. Reg Environ Change 13(3):681-694

Herzog TR (1985) A cognitive analysis of preference for waterscapes. J Environ Psychol 5:225-241

Hill D, Daniel TC (2008) Foundations for an ecological aesthetic: Can information alter landscape preferences? Soc Nat Resour 21:34-49

Hull RB (1986) Sensitivity of scenic beauty assessments. Landsc Urban Plan 13:319-321

Jacques DL (1980) Landscape appraisal: the case for a subjective theory. J Environ Manage 10:107-113

Janecki J (1978) The straight line in the assessment of landscape value (in Polish). Problemy 10:9-10

Jongman RHG (2002) Homogenization and fragmentation of the European landscape: ecological consequences and solutions. Landsc Urban Plan 58:211-221

Kułak A, Chmielewski T J (2010) Changes in the physiognomy of the landscape of the West Polesie from the middle of the 19th century till the beginning of the 21st century. In: Chmielewski TJ, Piasecki D (ed) The Future of Hydrogenic Landscapes in European Biosphere Reserves. University of Life Sciences in Lublin; Polesie National Park; Polish Academy of SciencesBranch in Lublin; National UNESCO-MaB Committee of Poland. Lublin, pp 29-40

Law CS, Zube EH (1983) Effects of photographic composition on landscape perception. Landsc Res 8(1):22-23

Lee JT, Elton MJ, Thompson S (1999) The role of GIS in landscape assessment: using land-use-based criteria for an area of the Chiltern Hills Area of Outstanding Natural Beauty. Land Use Policy 16(1):23-32

Li BL (2000) Why is the holistic approach becoming so important in landscape ecology? Landsc Urban Plan 50:27-47

Lindenmeyer DB, Fisher J (2006) Habitat Fragmentation and Landscape Change. An ecological and conservation synthesis. Island Press, Washington, pp 1-352

LSDCELC (2006) Landscape and Sustainable Development Challenges of the European Landscape Convention. Council of Europe Publishment. Strasburg, pp 1-214

Meire E, Frankl A, De Wulf A, Mitiku H, Deckers J, Nyssen J (2013) Land use and cover dynamics in Africa since the nineteenth 
century: warped terrestial photographs of North Ethiopia. Reg Environ Change 13(3):717-737

Myczkowski Z (2003) Landscape as the expression of identity in selected protected areas in Poland (in Polish). Politechnika Krakowska, Kraków, pp 1-228

Myczkowski Z (2009) Genius loci in landscape (in Polish). In: Gutowski P (ed) Fenomen genius loci. Tożsamość miejsca w kontekście historycznym i współczesnym. Wyd. Muzeum Pałac w Wilanowie; Warszawa, pp 153-162

Myczkowski Z (2012) A record of village cultural heritage in the context of changes of the genius loci in landscape (in Polish). Architektura Krajobrazu 23(2): 59-70

Naveh Z (2001) Ten major premises for a holistic conception of multifunctional landscapes. Landsc Urban Plan 57:269-284

Ohta H (2001) A phenomenological approach to natural landscape cognition. J Environ Psychol 21(4):387-403

Orland B, Weidemann E, Larsen L, Radja P (1995) Exploring the relationship between visual complexity and perceived beauty. Imaging Systems Laboratory, Department of Landscape Architecture, University of Illinois at Urbana-Champaign: (http:// www.macaulay.ac.uk/ccw/task-two/evaluate.html)

Patoczka P (2000) Walls and gates in landscape (in Polish). Politechnika Krakowska. Seria Architektura. Monografia nr 268. Kraków: 1-191

Ramirez A, Ayuga-Tellez E, Gallego E, Fuentes JM, García AI (2011) A simplified model to assess landscape quality from rural roads in Spain. Agric Ecosyst Environ 142(3-4):205-212

Roth M (2006) Validating the use of Internet survey techniques in visual landscape assessment-An empirical study from Germany. Landscape and Urban Planning. Vol. 78, Issue 3, 9 November 2006: 179-192
Rylke J, Gąsowska M (2009) Values of rural and industrial landscape for the development of recreation, on the example of Warmia villages and the Elblagg Canal (in Polish). Nauka Przyr. Techno. $3(1): 1-10$

Shuttleworth S (1980) The evaluation of landscape quality. Landsc Res 5:14-20

Skalski JA (2007) Landscape perception analysis as creative activity initiating the process of design (in Polish). Wydawnictwo SGGW, Warszawa, pp 1-245

Söhngen HH (1975) Die Bewertung von Landschaftbestandteilen für die landschaftplanerische Begleitplannung in der Flurbereinigung. In: Natur und Landschaft, 10, Stuttgart: pp 274-275

Southworth J, Nagendra H, Tucker C (2002) Fragmentation of a Landscape: Incorporating landscape metrics into satellite analyses of land-cover change. Landscape Research. 27(3):253-269

Wejchert K (1984) Elements of urbanistic composition (in Polish). Wydawnictwo Arkady, Warszawa, pp 1-279

West Sellars R (2009) Preserving nature in the national parks. A history. Yale University Press, New Haven, pp 1-404

Wojciechowski KH (1986) Problems of landscape perception and aesthetic assessment (in Polish). Uniwersytet Marii CurieSkłodowskiej, Lublin, pp 1-283

Wu Y, Bishop I, Hossain H, Sposito V (2006) Using GIS in landscape quality assessment. Applied GIS. Monash Uniwersity Press. Vol. 2(3), pp 18.1-18.20

Zonneveld I, Forman RTT (eds) (1990) Changing landscapes: an ecological perspective. Springer, New York, pp 1-281 